\title{
CIRIL STANIČ, NAJSTAREJŠI UČEČI SE SLOVENEC
}

Ko sem se odpravljala na prvi pogovor s 97 letnim Cirilom Staničem, sem imela v mislih predvsem gospoda $\mathrm{z}$ bogato preteklostjo. Vrata svojega doma in duše pa mi je $v$ Ljubljani odprl gospod, ki živi in se uči za danes in jutri. Po drugem, javnem pogovoru konec lanskega leta na portoroški konferenci Izobraževalni management je najstarejši učeči se Slovenec tudi druge prepričal v moč vseživljenjskega učenja.

In kdo je pravzaprav Ciril Stanič? Nadvse vitalen gospod, ki je pri 96. letih postal bruc, saj se je vpisal v prvi letnik na oddelku za gradbeništvo Fakultete za urbanizem, arhitekturo in gradbeništvo Univerze $v$ Ljubljani. Rodil se je v Kanalu ob Soči. V Ljubljani je končal realko, šolanje pa nadaljeval na strojni in srednji gradbeni šoli. $\mathrm{Za}$ njim je bogata poklicna kariera vrhunskega gradbenika za vodne, cestne in visoke gradnje. Dela in funkcij mu nikoli ni zmanjkalo, prav tako ne nagrad, pohval in priznanj-tudi po upokojitvi ne.

Njegovih je več kot 800 projektov in idej, poleg gradbeništva pa ga zanimata tudi arhitektura in urbanizem. Je ekolog, planinec, telovadec, ribič ... Dokaz, da je aktiven še danes, je med drugim njegova udeležba na slovenskem kongresu o cestah in prometu leta 2000 na Bledu, kjer je predstavil svoje načrte za Posočje.

\section{Zakaj ste se pri svojih 96-tih letih vpisali na fakulteto?}

C. Stanič: Ko sem končal nemško realko, je veljalo le eno: samo delaj! Govorili so mi: Ciril, ti greš tja! Ti boš to naredil! Ti boš tisto naredil! Takrat nisem bil gospodar svojega telesa, nisem bil več last samega sebe. Kamor sem prišel, so bili tako zadovoljni z mano, da me niso hoteli dati stran. Med drugim sem bil trikrat direktor uprave cest in enkrat sem se hotel izmuzniti, da bi kaj drugega začel. Pa ni šlo. Direktor boš!, so rekli, in človek je ubogal. Potem so me poslali za dve leti v Črno goro. Pa še danes ne vem, ali zato, ker sem bil doma prehud, ali zato, ker je Črna gora rabila tako neustrašne dedce. $\mathrm{Pa}$ ne zaradi žensk! Taki časi so bili. Kamor so te dali, tja si šel.

Ko sem hotel na fakulteto, so mi rekli: Poglej, Ciril. Ti so dozorel človek. Saj nihče od tebe ne zahteva, da bi bil šolan! In jaz sem trpel. Ko je vse skupaj prišlo tako daleč, da sem ostal zadaj, sem zbral tiste moje načrte, programe, projekte in štartal. Šel sem na fakulteto in rekel: Lepo prosim, Ciril Stanič se želi vpisati na fakulteto. Zakaj? Tukaj je moje delo! In sem prinesel tja en šop teh mojih programov, planov, izvršenih del. Dobil sem indeks in tako postal "fakultetar", Zdaj lahko jaz svojim pobom (med njimi so tudi dohtarji pa magistri) rečem: Pazite se otroci, drugače bo oče šel še naprej in še magistraturo delal! $\mathrm{Pa}$ to ni noben bav bav!

\section{Od kod vam taka ljubezen do gradbeništva?}

C. Stanič; Od prvega dne, ko je učitelj v naših takrat še avstrijskih "risankah" naredil premo 
črtico ali lok, sem tako požiral vse to, da se nisem potem nikoli več rešil črtanja, risanja. To je za mene evangelij vse dejavnosti strokovnjaka.

\section{In kaj sicer delate doma?}

C. Stanič: Vse za stari ljubljanski avtobusni kolodvor in vse za novi železniški in avtobusni kolodvor. Že dvajset let zbiram gradivo za in proti.

\section{Ste zaljubljeni?}

C. Stanič: Zaljubljen? Jaz sem zaljubljen v urbanizem, stroko. Če le kje opazim, da nekaj ni v redu, takoj pišem, rišem in skiciram.

\section{Nekateri se bojijo starosti. Je ta strah upravičen?}

C. Stanič: Šele ko sem šel v pokoj, sem začel živeti, ker sem šele takrat bil sproščen.

\section{Koliko let ste upokojenec?}

\section{Stanič: Dvainštirideset let.}

\section{Kakšno je življenje po upokojitvi?}

C. Stanič: Življenje po življenju. Kariera in učenje se ne končata po formalno pridobljeni izobrazbi.

\section{Kljub svojim letom ste zelo dejavni ...}

C. Stanič: Bolj ko je človek aktiven, bolj je živ. Jaz živim polno, aktivno življenje. Znam tudi plesati, peti ...

\section{Od kod vam moč in volja za delo, učenje, spoznavanje novega?}

C. Stanič; Človek je živo bitje. Če nisi živ, si živ mrlič. Samo živ človek gre gor in dol, samo živ človek govori, samo živ človek pogleda dekle, pa mu srce hitreje bije. Živ človek! To je velikanska razlika! Tudi izobraževanje gre naprej. Če se odločiš, da boš na primer obvladal angleščino, je v tvojih rokah, ali jo boš res ali ne. Jaz obvladam tri, štiri jezike, pa ne tako, da boste rekli, no, pa napiši zdaj kaj, ampak obvladam. Doma sem naročen na časopise. Če ne preberem Dela, Dnevnika in podobno, nisem prisoten. To mora človeku priti v kri, telo in "betico". Tudi to je neka izobraževalna zagrizenost.

\section{Kaj je potemtakem znanje?}

C. Stanič: Znanje je življenjska zaloga vseh tvojih ustvarjalnih in življenjsko človeških izvrševalnih del.

In ker je pravzaprav nemogoče našteti, kaj vse je Ciril Stanič kot gradbenik do danes ustvaril, naredil, velja omeniti vsaj nekaj del, na katera je najbolj ponosen. To so: Sokolski dom v Trnovem v Ljubljani, njegova domača hiگ̌a v alpskem slogu, napeljava žičnice na Komno in prvi hotel v Črni gori.

\section{Kako deliti lastno znanje $\mathrm{z}$ drugimi, kako se učiti?}

C. Stanič: Sočloveku moraš želeti dobro $\mathrm{z}$ dejanji, ne $\mathrm{z}$ besedami. Sebe moraš postaviti na ogled, tribuno. Vzemite od mene, kar je dobrega, pa boste od mene odnesli največ.

\section{V vseh teh letih vam ni zmanjkalo energije. Kaj vas danes drži pokonci?}

C. Stanič: Vsak dan se postavim v pogon. Moram si pripraviti, kaj bom naredil jutri, da me to potem drži pokonci. Imam škatlo, v katero dam različne stvari, ki jih moram urediti naslednji dan. Kar sem danes zasledil, da je vredno sebi dati za spomin, je v škatli: članki, karikature ...

In res je njegovo življenje natančno 
organizirano. V predalih, na policah, v mapah, škatlah z napisi Bosna, Črna gora, Evropa, Osimski sporazum, Amerika, Rusija, Trenta, Kongresi, Zgodovina cest, Plečnik, Razno, Nujno, Vabila ... so shranjeni dokumenti, načrti, kilometri in kilometri projektiranih cest. Tudi njegovo življenje danes teče po določenem urniku. Vstane pred osmo, potem pa si z mrzlo vodno masažo okrepi telo in predrami duha. Sledi rekreacija - petdeset počepov in nekaj drugih telovadnih vaj - pa zajtrk. Nato se loti načrtovanega dela. Ko je čas za kosilo, se ponj odpravi v bližnji vrtec. In tako vsak dan vedno znova $\mathrm{z}$ lahkoto premaguje šestinpetdeset stopnic do svojega podstrešnega stanovanja $v$ hiši.

Kako poleg jutranje rekreacije še skrbite za zdrav duh v zdravem telesu? Kako ohranjate fizično kondicijo?

C. Stanič: Enkrat na teden sem v telovadnici, kjer telovadim.

\section{In kdo še $\mathrm{z}$ vami?}

C. Stanič: Dva šestdesetletnika, sicer pa jih je večina starih od šestnajst do trideset let.

\section{Kaj je pravzaprav pomembno $\mathrm{v}$ življenju?}

C. Stanič: Vsak trenutek moraš biti gospodar svojega življenja. Jaz delam, ker hočem živeti. Verjamem v sebe.

Ne vem, če si kdo zna predstavljati sebe pri osemdesetih, devetdesetih letih, koliko vedoželjnosti bo v nas, koliko življenja. Če bomo zmogli imeti toliko želja in volje, kot jo ima Ciril Stanič danes, pri 97-ih letih, bomo zagotovo srečni.

\section{Milica Prešeren}

